\title{
A New Species of the Genus Asemonea (Araneae: Salticidae) from Japan
}

\author{
Hiroyoshi IKEDA ${ }^{1)}$
}

$$
\begin{gathered}
\text { 池田博明1)：日本産ヨリメハエトリグモ属 } \\
\text { (クモ目：ハエトリグモ科）の } 1 \text { 新種 }
\end{gathered}
$$

\begin{abstract}
A new salticid spider species, Asemonea tanikawai sp. nov. is described on the basis of the materials obtained from Iriomotejima Island, Okinawa Pref., Japan. The genus Asemonea is newly recorded from Japan.
\end{abstract}

Recently, I examined the spider specimens collected by Akio TANIKAWA from Iriomotejima Island, Okinawa Pref., Japan. In these specimens, I recognized a new species of the genus Asemonea occurring in the island. It will be described in the present paper.

Up to the present, 13 species of the genus Asemonea were described from Africa and East Asia (W ANLess, 1980; PlATNICK, 1989; PrósZYN̄SKI, 1990). The genus Asemonea belongs to the subfamily Lyssomaninae and the spiders of the genus have eyes in four rows. Another genus of the subfamily, Onomastus, was recorded from Japan (ONO, 1995; the generic name was misspelled as Onomustus).

The type specimens designated in this paper are deposited in the collection of the Department of Zoology, National Science Museum (Nat. Hist.), Tokyo.

The following abbreviations are used: ALE, anterior lateral eye; AME, anterior median eye; PLE, posterior lateral eye; PME, posterior median eye; RTA, retrolateral tibial apophysis. The distances between eyes are presented with a dash, e. g., ALEALE indicates distance between ALEs.

\section{Genus Asemonea O. P.-CAMBRIDGE, 1869}

Asemonea O. P.-CAMBridge, 1869: 65. Type species: Lyssomanes tenuipes O. P.-CAMBrIDGE, from Sri Lanka.

Diagnosis. Spiders small to medium size, i. e. total length between 2.6 and $7.0 \mathrm{~mm}$. Eyes: Usually with black surrounds except AME; AME the largest, almost occupying full breadth of face. This genus is distinguished from related genera by eye arrangement as shown in WANLESS (1980). Male palp: Femora with ventral furrow. Epigynum: Atrium undivided, with median septum, or covered by median scape.

Distribution. Africa (Liberia, Angola, Kenya, Ivory Coast, Ghana, Ginea, Mali, Zaire, Madagascar), Andaman Islands, Burma, India, Sri Lanka, Malaysia, Pinang

1) 1099, Kanade, Ôimachi, Ashigarakami-gun, Kanagawa, 258 Japan

广 258 神奈川県足柄上郡大井町金手 1099

Accepted October 9, 1996 
Island, Thailand and Japan.

Asemonea tanikawai sp. nov.

(Figs. 1-11)

Salticidae sp. (A): CHIKUNI,1989, pp. 157, 286, fig. 51.

Specimens examined. Holotype: $\sigma^{7}$, Ôhara, Iriomotejima Island, Okinawa Pref., 30-III-1986, A. TANIKAWA leg. (NSMT-Ar 3318). Paratypes: 3 우, same data as for the holotype (NSMT-Ar 3319).

Description. Measurement of the type specimens (in $\mathrm{mm}$ ); variation in parentheses. Body length ơ 3.36, 우 3.36 (3.26-4.16); prosoma length ơ 1.44, 우 1.44 (1.31-1.60), width ơ 1.22, 우 $1.09(0.99-1.28)$, height ơ 0.80 , 우 $0.80(0.80-0.89)$; opisthosoma length or 1.92, 우 $1.92(1.84-2.24)$, width or 0.80, 우 $0.80(0.80-1.12)$. Eye fields: ALEALE o 0.90, 우 0.93 (0.88-1.01), ALE-PLE o 0.54, 우 0.54 (0.51-0.60), PME-PME

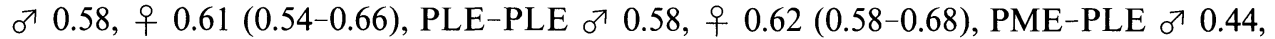
우 0.45 (0.44-0.46); $\mathrm{AME}$ diameter 구 0.32, 우 0.34 (0.32-0.35), ALE/AME 이 0.55, 우 0.52 (0.52-0.60), ALE/PLE ơ 1.22, 우 1.22 (1.22-1.41), PME/PLE ơ 0.89, 우 0.89 (0.71-0.89). ALE greater than half the diameter of AME, PME large, clearly situated inside optical axis of ALE. PLE set well inside lateral margins of prosoma; quadrangle formed by PME and PLE broader than long.
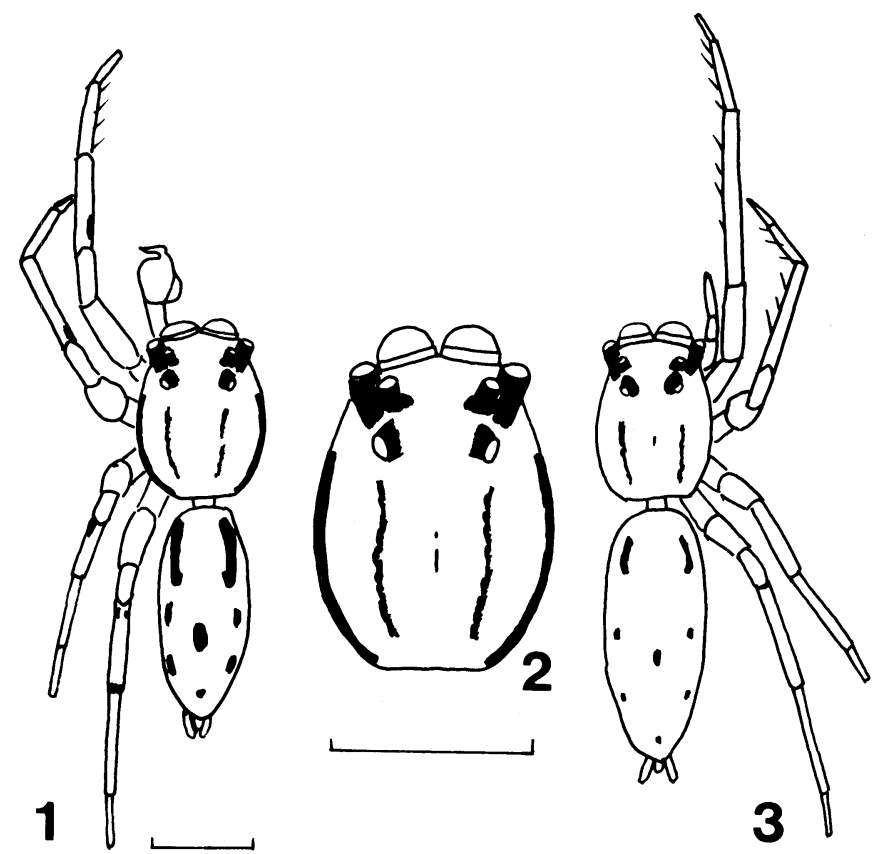

Figs. 1-3. Asemonea tanikawai sp. nov. —- 1, Male, dorsal view; 2, male prosoma, dorsal view; 3 , female, dorsal view (scales: $1.0 \mathrm{~mm}$ ). 

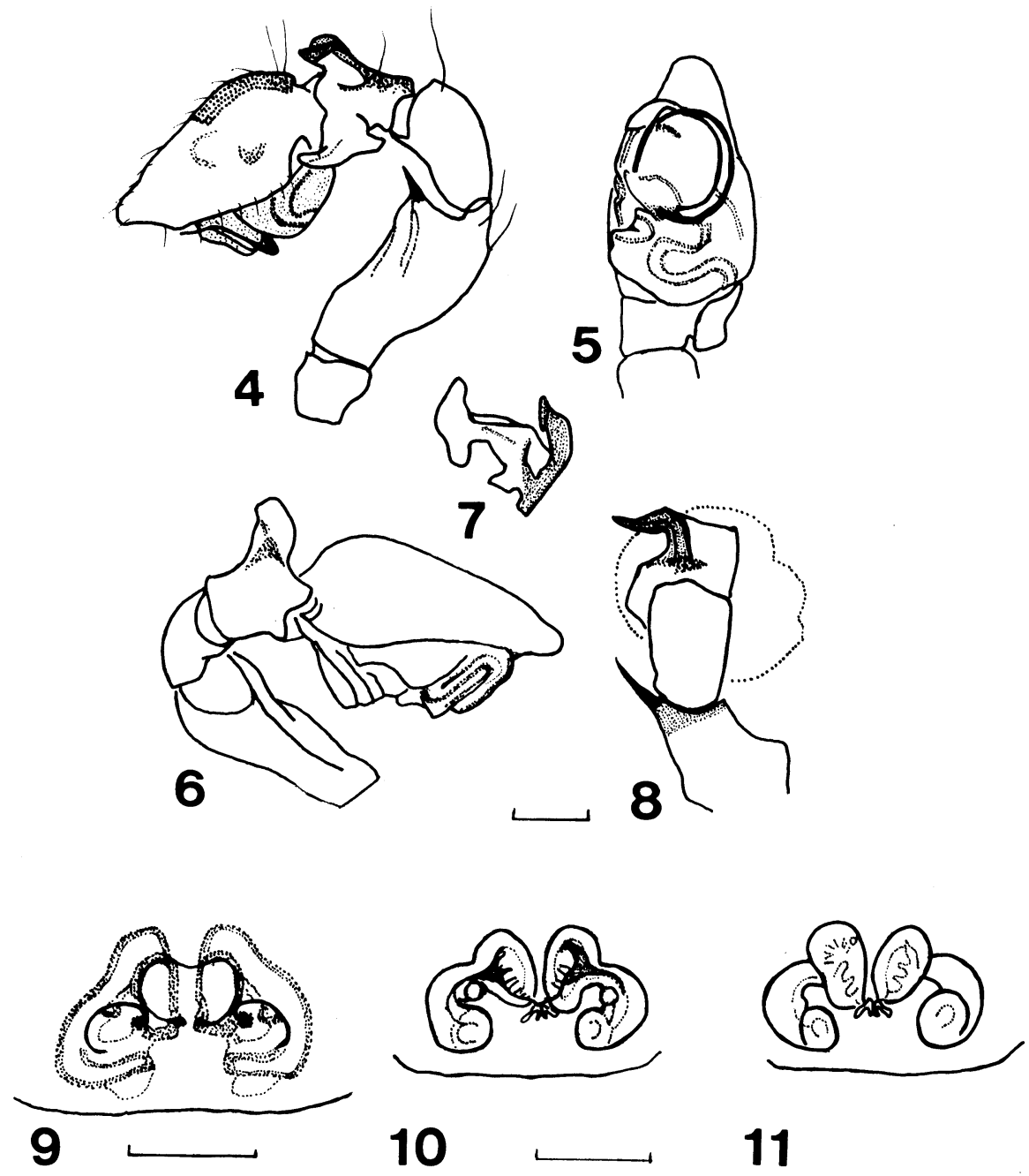

Figs. 4-11. Asemonea tanikawai sp. nov. —— 4, Male palp, retrolateral view; 5, same, ventral view; 6 , same, prolateral view, 7, retrolateral tibial apophysis; 8 , tibial apophysis and femoral apophysis, dorsal view; 9, epigynum; 10, female genitalia, ventral view; 11, same, dorsal view (scales: $0.2 \mathrm{~mm}$ ).

Legs. Length of legs of the holotype and a paratype 우 as shown in Table 1. Formation of spines of legs of the same specimens as shown in Table 2.

Male palp (Figs. 4-8). Complex, tibial apophysis characteristic. Femora with ventral furrow and apical apophysis, patella without apophysis. Embolus long and curved, arising from basal margin of tegulum, free from embolic guide, but resting distally in lateral tegular groove. Tegulum ovoid in ventral view, margins modified to form embolic guide, subtegulum bulbus, with sinuous ducts.

Female genitalia (Figs. 9-11). Copulatory openings invisible, spermathecae 
Table 1. Measurement of leg segments of Asemonea tanikawai sp. nov. ( $\mathrm{mm})$.

\begin{tabular}{ccccccc}
\hline Leg & Femur & Patella & Tibia & Metatarsus & Tarsus & Total \\
\hline I & $1.28 / 1.28$ & $0.48 / 0.50$ & $1.18 / 1.20$ & $0.98 / 1.04$ & $0.37 / 0.34$ & $4.29 / 4.36$ \\
II & $1.12 / 1.12$ & $0.45 / 0.45$ & $0.98 / 0.99$ & $0.85 / 0.86$ & $0.35 / 0.32$ & $3.75 / 3.74$ \\
III & $1.10 / 1.04$ & $0.43 / 0.45$ & $0.88 / 0.90$ & $0.96 / 0.98$ & $0.45 / 0.39$ & $3.82 / 3.76$ \\
IV & $1.31 / 1.39$ & $0.45 / 0.48$ & $1.26 / 1.33$ & $1.30 / 1.28$ & $0.50 / 0.45$ & $4.82 / 4.93$ \\
\hline
\end{tabular}

Table 2. Formation of spines of legs of Asemonea tanikawai sp. nov. (dorsal/ ventral, none $=$ no spine, $\mathrm{p}=$ prolateral, $\mathrm{r}=$ retrolateral).

\begin{tabular}{|c|c|c|c|c|}
\hline \multicolumn{2}{|c|}{ Leg } & Femur & Tibia & Metatarsus \\
\hline \multirow[t]{2}{*}{$\mathrm{I}$} & $0^{7}$ & $0-1-1-1 \cdot 2 p /$ none & $0-0-1 \mathrm{p}-0-0 / 2-2-2-2-0$ & $1 \mathrm{p}-1 \mathrm{p}-0-0-0 / 2-2-2-2-0$ \\
\hline & 우 & $0-1-1-1 \cdot 2 \mathrm{p} /$ none & $0-0-1 \mathrm{p}-0-0 / 2-2-2-2-0$ & none $/ 2-2-2-2-0$ \\
\hline \multirow[t]{2}{*}{ II } & वर & $0-1-1-1 \cdot 1 \mathrm{p} /$ none & $0-2-1 \mathrm{r}-0 / 2-2-2-2-0$ & $1 p-0-1 p-0-0 / 2-2-2-2-0$ \\
\hline & 우 & $0-1-1-1 \cdot 1 \mathrm{p} /$ none & $0-1 p-0-0 / 2-2-2-2-0$ & $1 p-0-1 p-0-0 / 2-2-2-2-0$ \\
\hline \multirow[t]{2}{*}{ III } & $0^{7}$ & $0-0-1-3 /$ none & $1 r-2-0-2 / 0-0-1 p-2$ & $0-2-2-0 / 2-0-2-2$ \\
\hline & 우 & $0-0-1-3 /$ none & $0-2-0-2 /$ none & $0-2-2-0 / 2-0-2-2$ \\
\hline \multirow[t]{2}{*}{ IV } & वा & $0-0-1-3 /$ none & $2-0-3 / 1 p-1 p-0$ & $2-0-2-2 / 1 p-1 r-0-2-2$ \\
\hline & 우 & $0-0-1-3 /$ none & $0-0-2-0 / 1 \mathrm{p}-2-2$ & $0-2-2-0 / 0-0-2-2$ \\
\hline
\end{tabular}

behind the undivided atrium. Accessory glands present.

Coloration and markings in ethanol (Figs. 1-3). Male: Prosoma whitish yellow with white hairs, a pair of brown longitudinal stripes and brown margin of thoracic part. Fovea long. Eyes with black surrounds except AME, fringed by white hairs. PLE behind with orange hairs. Clypeus whitish yellow, marked with a pair of black spots below AME with white hairs. Chelicerae, maxillae and labium white. Sternum whitish yellow covered with white hairs. Opisthosoma dorsum whitish yellow with nine black spots, clothed with brown hairs. Venter of opisthosoma whitish yellow with white hairs. Leg I: All segments whitish yellow with black spots on lateral side of both the ends of tibia and femoral distal end. The coloration of the remaining legs as same as that of leg I.

Female: Same as in male, but brown margin of prosoma and black spots below AME and white hairs behind PLE lacking. Black spots present at tibial ends of legs III and IV. The other segments of legs white, without spots.

Distribution. Japan [Iriomotejima Is. and Okinawa Is. (ONO, pers. comm.)]. CHIKUNI (1989) described that this species was widely distributed in Okinawa Prefecture.

Remarks. This species resembles Asemonea maculata WANLESS, 1980 from Ivory Coast in the colour pattern and Asemonea pinangensis WANLESS, 1980 from Pinang Island, Malaysia in the male palpal figure, but can be distinguished from these species by the shape of dorsal tibial apophysis and femoral apophysis of the male palp.

Etymology. This species is dedicated to Mr. Akio TANIKAWA who collected the specimens of the new species.

\section{Acknowledgements}

I wish to express my hearty thanks to Dr. Hirotsugu ONO, National Science Museum 
(Nat. Hist.), Tokyo, for his constant guidance and for critically reading the manuscript of this paper, and to Mr. Akio TANIKAWA, Kanagawa for offering the specimens used in this paper.

\section{摘要}

西表島産の標本に基づいて，Asemonea ヨリメハエトリグモ属（新称）の 1 新種 Asemonea tanikawai タニカワヨリメハエトリ（新称）を記載した。ヨリメハエトリグモ 属はリセイハエトリグモ亜科に属し，日本新記録属である.

\section{References}

ChIKUnI,Y., 1989. Pictorial Encyclopedia of Spiders in Japan. 308pp. Kaiseisha, Tokyo. (In Japanese.)

ONO, H., 1995. Four East Asian spiders of the families Eresidae, Araneidae, Thomisidae and Salticidae (Arachnida, Araneae). Bull. natn. Sci. Mus., Tokyo, Ser. A, 21: 157-169.

PiCKARD-CAmbridge, O., 1869. Descriptions and sketches of some new species of Araneida, with characters of a new genus. Ann. Mag. Nat. Hist., (4) 3:52-74, pls. IV-VI.

PlatNiCK, N. I., 1989. Advances in Spider Taxonomy, 1981-1987. 673 pp. Manchester University Press.

PrósZYŃski, J., 1990. Catalogue of Salticidae (Araneae). 366 pp. WSRP, Siedlce.

Wanless, F. R., 1980. A revision of the spider genera Asemonea and Pandisus (Araneae: Salticidae). Bull. Br. Mus. nat. Hist., Zool., 39: 213-257. 